\title{
Immunoglobulin E and Serum Interleukin-4 in Patients with Alopecia Areata and Its Correlation to the Severity of the Disease
}

\author{
(1) Reham Abd El-Latif ${ }^{1}$, (1) Ghada F. Mohammed', (1) Fadia Attia², (1) Moustafa Eyada ${ }^{1}$ \\ 1Suez Canal University Faculty of Medicine, Department of Dermatology and Venereology, Ismailia, Egypt \\ ${ }^{2}$ Suez Canal University Faculty of Medicine, Department of Clinical and Chemical Pathology, Ismailia, Egypt
}

\section{ABSTRACT}

Background: Alopecia areata (AA) is a common form of non-scarring hair loss. The eatio-pathogenesis AA is unknown. To assess serum level of immunoglobulin E (IgE) and interleukin-4 (IL-4) and in patients with AA and its correlation to severity of the disease.

Materials and Methods: Fifty-seven patients with AA [38 (66.6\%) females and 19 (33.3\%) males]; and 17 normal volunteer enrolled in the study. Serum level IgE and IL-4 assessed by enzyme-linked immunosorbent assay and severity of AA assessed with Severity of Alopecia Tool.

Results: The study included 57 patients with AA [38 (66.6\%) females and 19 (33.3\%) males]; among them, there were 28 patients (49.1\%) with LAA, 10 (17.5\%) with AT, and 19 (33.4\%) with AU. The difference of IgE and IL-4 levels between different age groups was statistically significant among both cases and controls $(p \leq 0.05)$. The difference between IgE and IL-4 levels and severity of AA was statistically highly significant $(p \leq 0.05)$.

Conclusion: IgE and IL-4 levels are elevated in patients with AA. The elevation of IgE and IL-4 is positively correlated the increasing severity of disease. This suggests a shift from a T-helper1 response in early AA to chronic Th2 immune profile.

Keywords: Alopecia areata, IgE, IL-4, Pathogenesis, SALT

\section{Introduction}

Alopecia areata (AA) is an unpredictable, medical condition in which there is nonscarring hair loss from some or all hair-bearing areas of the body, usually from the scalp [1,2]. According to the hair loss extension, AA classified into localized or patchy AA (LAA), complete loss scalp hair or alopecia totalis, and total body hair loss with alopecia universalis (AU) [3]. The pathogenesis is complex and involve the interplay of multiple factors, as immunological, environmental, psychological, and genetic factors; however, the exact factors are unknown [4].

Role of cellular immunity and T-helper1 (Th1) cytokines as interferon- $\gamma($ IFN- $\gamma$ ) and interleukin-2 (IL-2) in AA was reported [5], humeral immunity and Th2 cytokines as (IL-4, IL-5 and IL-13) are also incriminated in the pathogenesis of AA $[6,7]$. IL-4 and IL-13 stimulate the transcription of IgE in B-cells through Ig constant region genes $[8,9]$. Unfortunately, the mechanism in which IL-4 and IgE may interact in the pathogenesis of AA is unknown $[6,10,11]$

Therefore, the aim of this study was to assess serum IL-4 and IgE levels of in Egyptian patients with different clinical forms of $A A$ without atopic background and healthy subjects. Also to investigate the relation between these levels to the severity of AA using Severity of Alopecia Tool (SALT).

This study conducted to assess the level of IL-4 and IgE in patients with AA and its correlation to severity of the disease. 


\section{Materials and Methods}

This pilot, parallel group and randomized controlled trial conducted over 12 months. It received an approval from the Institutional Research Review Board Ethical Committee of the Suez Canal University, Faculty of Medicine, Ismailia, Egypt (decision number: 788). It conducted in accordance with the guidelines of the Helsinki Declaration and performed after obtaining the informed consent from all participants.

Inclusion criteria for this study included non-atopic AA with no evidence of any systemic autoimmune diseases (as Hashimoto's thyroiditis) or dermatologic disease as (atopic dermatitis or vitiligo). Exclusion criteria included pregnant women, lactating women, and patients who were receiving treatment for AA, sessions of PUVA, for at least six months before this study. Sixty-three patients were eligible for participation, and 57 completed the study. Complete medical history obtained from each patient, and underwent a general physical examination, stool analysis to exclude parasitic infestation, skin prick test to a panel of allergens, complete blood count to determine the number of eosinophils, and assessment of serum levels of anti-thyroid peroxidase antibodies in those had clinically suggestion of Hashimoto's thyroiditis. In addition to clinical assessment of AA SALT, a formalized mathematical approach for the determination of hair loss and hair regrowth. Briefly, the \% of scalp hair loss in each of the sides, back and top of the scalp were determined independently, each was multiplied by the $\%$ scalp covered in that area of the scalp and the products of each section summed for a final total $\%$ hair loss designed as SALT score [12].

Both patients and controls were subjected to determination of serum IL-4 levels using enzyme-linked immunosorbent assay (ELISA) technique and IgE levels using microparticle enzyme immunoassay technique AviBion Human IL4 ELISA Kit. FINLAND for IL4 and Monobind Inc. USA for IgE. The assay performed blindly on coded samples by a blinded investigator, after the collection of all samples had been completed. In healthy, non-allergic adults, reference range of IgE in children and adult was up to $60 \mathrm{IU} / \mathrm{mL}$ and less than $120 \mathrm{IU} / \mathrm{mL}$ respectively.

\section{Statistical Analysis}

Statistical analysis carried out using computer program Statistical Package for the Social Science (SPSS) version 16 (SPSS; Inc., Chicago, IL, USA). A probability value ( $p$ value) $<0.05$ considered statistically significant. Qualitative data were analyzed using chi-square test while quantitative data analyzed by Kruskal-Wallis and MannWhitney test. Pearson correlation coefficient was for IgE and IL-4. The probability of error at 0.05 considered significant, while at 0.01 is highly significant.

\section{Results}

The study included 57 patients with AA [38 (66.6\%) females and 19 (33.3\%) males]; among them, there were 28 patients (49.1\%) with LAA, 10 (17.5\%) with AT, and 19 (33.4\%) with AU. The mean age of enrolled patients was $28 \pm 7.8$ years, ranging from six to 47 years. The duration of AA ranged from two weeks to 13 years with a mean of 21.4 months. There were 24 patients (42.1\%) with positive family history of AA. Thirty-seven patients (64.9\%) showed a relation between the onset of their disease and a preceding period of stress, while 20 (35.1\%) stated no relation to stress (Table 1). SALT score according to patients showed in Table 2.

The difference of IgE and IL-4 levels between different age groups was statistically significant among both cases and controls $(p \leq 0.05)$ (Table 3). The difference between IgE and IL-4 levels and severity of AA was statistically highly significant (Table 4). In addition, there were strong significant positive correlation between these levels and duration of disease and SALT score (severity of disease) ( $p$ value $<0.05$ ), but not with age or gender ( $p$ value $>0.05$ ) (Table 5 ).

\section{Discussion}

Many mouse and human data revealed that the initiation phase of AA is heavily Th1- based immune response, while the maintenance of hair follicle destruction by cytotoxic cells is due to shift from Th1 response to more chronic Th-2 immune response [13]. Although

\section{Table 1. Disease characteristics among cases}

\begin{tabular}{|l|l|}
\hline Age & $28 \pm 7.8$ \\
\hline Mean \pm SD & $6-47$ \\
\hline Range & \multicolumn{2}{|l|}{} \\
\hline Family history & $24(42.1 \%)$ \\
\hline Present n (\%) & $33(57.9 \%)$ \\
\hline Absent $n(\%)$ & \\
\hline Duration in months & $21.4 \pm 38.5$ \\
\hline Mean \pm SD & $0.5-676$ \\
\hline Range & \\
\hline Major life events & $37(64.9 \%)$ \\
\hline Present $n(\%)$ & $20(35.1 \%)$ \\
\hline Absent $n(\%)$ & \\
\hline SD: Standard deviation &
\end{tabular}

\section{Table 2. Severity of Alopecia Tool score of study cases}

\begin{tabular}{|l|l|l|}
\hline Score & No. & $\%$ \\
\hline S1 $(<25 \%)$ & 15 & 26.3 \\
\hline S2 $(25-49 \%)$ & 8 & 14 \\
\hline S3 $(50-74 \%)$ & 7 & 12.3 \\
\hline S4 (75-99\%) & 8 & 14 \\
\hline S5 (100\%) & 19 & 33.4 \\
\hline
\end{tabular}


Table 3. IgE E and IL-4 levels among different age groups of study subjects

\begin{tabular}{|c|c|c|c|c|c|c|}
\hline \multirow[b]{2}{*}{ Age group } & \multicolumn{2}{|c|}{ Number of patients } & \multicolumn{2}{|l|}{ IgE level } & \multicolumn{2}{|l|}{ IL-4 level } \\
\hline & Cases & Controls & $\begin{array}{l}\text { Cases }(n=57) \\
\text { Mean } \pm S D\end{array}$ & $\begin{array}{l}\text { Controls }(n=17) \\
\text { Mean } \pm \text { SD }\end{array}$ & $\begin{array}{l}\text { Cases }(n=57) \\
\text { Mean } \pm \text { SD }\end{array}$ & $\begin{array}{l}\text { Controls }(n=17) \\
\text { Mean } \pm \text { SD }\end{array}$ \\
\hline $15-<30$ yrs & 18 & 5 & $103 \pm 23.6$ & $13.7 \pm 8.4$ & $55.1 \pm 1.1$ & $40 \pm 5.2$ \\
\hline $30-<45$ yrs & 11 & 4 & $125.9 \pm 28.8$ & $18.5 \pm 3$ & $48.8 \pm 12.7$ & $55.6 \pm 6.5$ \\
\hline \multicolumn{3}{|l|}{ p value* } & $0.01 *$ & 0.08 & $0.02 *$ & 0.11 \\
\hline
\end{tabular}

Table 4. Comparison between IgE and IL-4 levels in different clinical forms of alopecia areata using Kruskal-Wallis test

\begin{tabular}{|l|l|l|}
\hline Type of alopecia & $\begin{array}{l}\text { IgE }(I U / m L) \\
\text { Mean } \pm \text { SD }\end{array}$ & $\begin{array}{l}\text { IL-4 }(\mathrm{Pg} / \mathrm{mL}) \\
\text { Mean } \pm \text { SD }\end{array}$ \\
\hline AU & $164.41 \pm 31.45$ & $57.11 \pm 21.1$ \\
\hline AT & $102.41 \pm 33.12$ & $33.31 \pm 51.9$ \\
\hline LAA & $72.41 \pm 11.25$ & $5.46 \pm 23.3$ \\
\hline Kruskal-Wallis & 29.16 & 27.81 \\
\hline p value & $<0.01^{* *}$ & $<0.01^{* *}$ \\
\hline
\end{tabular}

AU: Alopecia universalis, AT: Alopecia totalis, IgE: Immunoglobulin E, IL-4: Interleukin-4, SD: Standard deviation

Table 5. Correlation coefficients ( $r$ ) of age, gender, disease duration, and SALT score and with IgE and IL-4 levels

\begin{tabular}{|c|c|c|c|c|}
\hline \multirow[b]{2}{*}{ Variable } & \multicolumn{2}{|l|}{ IgE } & \multicolumn{2}{|l|}{ IL-4 } \\
\hline & $\begin{array}{l}\text { Correlation } \\
\text { coefficient ( } r^{\#)}\end{array}$ & p value & $\begin{array}{l}\text { Correlation } \\
\text { coefficient }\left(r^{\#}\right)\end{array}$ & $p$ value \\
\hline Age & 0.34 & 0.052 & 0.30 & 0.08 \\
\hline Gender & 0.25 & 0.06 & 0.13 & 0.47 \\
\hline $\begin{array}{l}\text { Duration } \\
\text { of } \\
\text { disease }\end{array}$ & 1.16 & $0.04 *$ & 1.25 & $0.02^{*}$ \\
\hline $\begin{array}{l}\text { SALT } \\
\text { score }\end{array}$ & 1.41 & $0.02 *$ & 1.42 & $0.01 *$ \\
\hline $\begin{array}{l}\text { *Significant } \\
\text { \#Spearman } \\
\text { SALT: Severit }\end{array}$ & $\begin{array}{l}\text { p value }<0.05 \text {. } \\
\text { rrelation was used. } \\
\text { of Alopecia Tool, IgE }\end{array}$ & . & in E, IL-4: Inter| & \\
\hline
\end{tabular}

increased levels of Th1 cytokines (IFN- $\gamma$ and IL-2) in lesional skin have been reported [14]. Th2 immune response is incriminated also in the eatio-pathogenesis of AA [11]. Cytokines derived from Th2cells (IL-4 and IL-13) can stimulate the transcription of IgE in B-cells through Ig constant region genes [10].

In human B-cells, the induction of IgE synthesis requires three types of signals. The first signal is delivered through the B-cell antigen receptor. The second signal is provided primarily by cytokines derived from Th2-cells, e.g. IL-4 and IL-13 that stimulate the transcription of IgE through the Ig constant region genes. Finally, the third signal is provided via the interaction between the constitutively expressed CD40 molecule on B-lymphocytes and CD154 (CD40 ligand), a molecule expressed on T-lymphocytes following activation $[9,10]$. IL-4 and IL-13 induced STAT6 signaling has been shown to play an important role in the differentiation of Th2-cells, B-cell induced expression of Ig-G and IgE and the cell surface display of MHC class II and CD23 [15].

The present study designed to investigate the role of IL-4 and IgE in the immuno-pathogenesis of AA and its correlation to its severity in patients with AA after exclusion of those with possible atopic disease. This in order to evaluate the role of immune signals to induce lgE; in AA patients, irrespective of atopic immune mechanisms. This study included 57 AA patients and other 17 healthy volunteers.

In 1977 O'Loughlin et al. [16], pointed to the association of serum IgE levels and AA. Later on, in 1986 Przybilla et al. [17], found elevated IgE in $19.7 \%$ in patients with AA. In the present study, the IgE and IL-4 levels were significantly higher in cases versus controls. Our result agreed with other studies [18,19,20,21,22]. On the other hand, other studies disagree with ours and showed non-significant difference [17,23,24,25].

Cytokines IL-4, 6, 7, 9, 13 enhance IgE production, but IFN- $\gamma$ and IL-10 inhibit the production [26]. So, high IL-4 and IgE levels may due to lower IL-10 [14], IFN- $\gamma$, and transforming growth factor-ß1 [11].

On the other hand, serum levels of IFN- $\gamma$ were significantly elevated in patients with extensive AA [27]. This may reflect the state of inflammation, especially in the extensive forms of the disease [28]. Therefore, the measurement of serum IFN- $\gamma$ could be a prognostic indicator to predict AU.

Tumor necrosis factor- $\alpha$ (TNF- $\alpha$ ) is synthesized in epidermal keratinocytes and is known to play a key role in the pathogenesis of AA [29]. It is a very potent inhibitor of proliferation [30] and creates a micro-environment rich in the Th2 cytokines, IL-4 and IL-13, enhancing IgE class switching [31]. 
In addition, the sera of patients with AA contain extremely high levels of B-cell activating factor (BAFF), which belongs to the TNF- $\alpha$ family [32]. BAFF is stimulated by IFN $-\gamma$ and increased in severe AA $[33,34]$.

Over expression of CD40 considered as another possible mechanism of IgE elevation in patients with AA [35]. It is suggested that CD40 stimulation alone could enhance IL-4 and IgE production [36]. As it present in the hair structures and dermal papilla of AA lesions pointing to its role in serum IL-4 and IgE elevation in patients with AA [37].

Regarding the relation of serum levels of both IL-4, IgE and the SALT score (for assessment of AA severity) and types of AA, we found that there was a strong positive correlation between each of IL-4, IgE and the severity of the disease assessed by SALT score. By comparing these results with previous studies, it comes in agreement with Attia et al. [19], 2010 as they found significant elevated serum IL-4 and IgE in patients with $\mathrm{AA}$, particularly $\mathrm{AU}$, irrespective of the presence of atopy. In contrast of our results, Teraki et al. [27], 1996 found significant elevated serum levels of IL-1 $\alpha$ and IL-4 in patients with the LAA, while there was significant elevated serum levels of IFN- $\gamma$ and IL-2 in patients with extensive forms. Katagiri et al. [11], 2007, suggested the same result, who found that the levels of IFN- $\gamma$ tended to increase while the levels of IL-4 tended to decrease in severe cases of alopecia. This could be explained by the fact that previous studies did not exclude patients with atopy and did not relate cytokine profile to disease chronicity.

This study revealed that psychic trauma precedes the onset of AA in 37 (64.9\%). This coincided with Güleç et al. [38], 2004, who reported that anxiety and depression play a major role in the etiopathogenesis of AA, and stressful life events may act as a trigger in the onset and/or exacerbation of the disease. Also the same finding was found by Manolache and Benea [39], 2007 who suggested that stress playes an important role in the onset and aggravation of both vitiligo and AA, often with one stressful event before disease onset.

The study showed a strong positive correlation between duration of the disease and IL-4 and IgE level. This was in agreement with Attia et al. [19], 2010 and Zuel Fakkar et al. [20], 2010 who found that the longer the disease duration was the higher the level of IL-4 and IgE was present.

\section{Conclusion}

Finally, IL-4 and IgE levels are elevated in patients with AA. Positive correlation of this elevation to the increasing severity of disease, suggests a shift from a Th1 response in early AA to a more chronic Th2 immune profile, with secondary B-cell stimulation and possible $\lg$ E class switching.

\section{Ethics}

Ethics Committee Approval: It received an approval from the Institutional Research Review Board Ethical Committee of the Suez Canal University, Faculty of Medicine, Ismailia, Egypt.

Informed Consent: It conducted in accordance with the guidelines of the Helsinki Declaration and performed after obtaining the informed consent from all participants.

Peer-review: Internally peer-reviewed.

\section{Authorship Contributions}

Surgical and Medical Practices: R.A.El-L., G.F.M., F.A., M.E., Concept: R.A.El-L., G.F.M., F.A., M.E., Design: R.A.El-L., G.F.M., F.A., M.E., Data Collection or Processing: R.A.El-L., G.F.M., F.A., M.E., Analysis or Interpretation: R.A.El-L., G.F.M., F.A., M.E., Literature Search: R.A.El-L., G.F.M., F.A., M.E., Writing: R.A.El-L., G.F.M., F.A., M.E.

Conflict of Interest: No conflict of interest was declared by the authors.

Financial Disclosure: The authors declared that this study received no financial support.

\section{References}

1. James WD, Berger TG, Elston DM, Odom RB. Andrews diseases of the skin: clinical. Dermatology 2006;207.

2. Madani S, Shapiro J. Alopecia areata update. J Am Acad Dermatol 2000;42:549-566.

3. Papadopoulos AJ, Schwartz RA, Janniger CK. Alopecia areata. Pathogenesis, diagnosis, and therapy. Am J Clin Dermatol 2000;1:101-105.

4. Hedstrand H, Perheentupa J, Ekwall 0, Gustafsson J, Michaëlsson G, Husebye $\mathrm{E}$, Rorsman $\mathrm{F}$, Kämpe $\mathrm{O}$. Antibodies against hair follicles are associated with alopecia totalis in autoimmune polyendocrine syndrome type I. J Invest Dermatol 1999;113:1054-1058.

5. Hoffmann R. The potential role of cytokines and T cells in alopecia areata. J Investig Dermatol Symp Proc 1999;4:235-238.

6. Jujo K, Renz H, Abe J, Gelfand EW, Leung DY. Decreased interferon gamma and increased interleukin-4 production in atopic dermatitis promotes IgE synthesis. J Allergy Clin Immunol 1992;90:323-331.

7. Shellow WV, Edwards JE, Koo JY. Profile of alopecia areata: a questionnaire analysis of patient and family. Int J Dermatol 1992;31:186-189.

8. Takhar P, Smurthwaite L, Coker HA, Fear DJ, Banfield GK, Carr VA, Durham SR, Gould HJ. Allergen drives class switching to IgE in the nasal mucosa in allergic rhinitis. J Immunol 2005;174:5024-5032.

9. Jelinek DF. Regulation of B lymphocyte differentiation. Ann Allergy Asthma Immunol 2000;84:375-385.

10. Bacharier LB, Geha RS. Molecular mechanisms of IgE regulation. J Allergy Clin Immunol 2000;105:547-558

11. Katagiri K, Arakawa S, Hatano Y. In vivo levels of IL-4, IL-10, TGF-beta1 and IFN-gamma mRNA of the peripheral blood mononuclear cells in patients with alopecia areata in comparison to those in patients with atopic dermatitis. Arch Dermatol Res 2007;298:397-401.

12. Olsen EA, Hordinsky MK, Price VH, Roberts JL, Shapiro J, Canfield D, Duvic M, King LE Jr, McMichael AJ, Randall VA, Turner ML, Sperling L, Whiting DA, Norris D; National Alopecia Areata Foundation. Alopecia areata investigational 
assessment guidelines--Part II. National Alopecia Areata Foundation. J Am Acad Dermatol 2004;51:440-447.

13. HogenEsch H, Torregrosa SE, Boggess D, Sundberg BA, Carroll J, Sundberg JP. Increased expression of type 2 cytokines in chronic proliferative dermatitis (cpdm) mutant mice and resolution of inflammation following treatment with IL-12. Eur J Immunol 2001;31:734-742.

14. Hoffmann R, Wenzel E, Huth A, van der Steen P, Schäufele M, Henninger HP, Happle R. Cytokine mRNA levels in Alopecia areata before and after treatment with the contact allergen diphenylcyclopropenone. J Invest Dermatol 1994;103:530-533.

15. Takeda K, Tanaka T, Shi W, Matsumoto M, Minami M, Kashiwamura S, Nakanishi K, Yoshida N, Kishimoto T, Akira S. Essential role of Stat6 in IL-4 signalling. Nature 1996;380:627-630.

16. O'Loughlin S, Diaz-Perez JL, Gleich GJ, Winkelmann RK. Serum IgE in dermatitis and dermatosis: an analysis of 497 cases. Arch Dermatol 1977;113:309-315.

17. Przybilla B, Ring J, Völk M. Gesamt-IgE-Spiegel im Serum bei dermatologischen Erkrankungen [Total IgE levels in the serum in dermatologic diseases]. Hautarzt 1986;37:77-82

18. Kasumagić-Halilović E, Prohić A. Serum levels of total immunoglobulin E in patients with alopecia areata: Relationship with clinical type of the disease. Acta Dermatovenerol Croat 2006;14:149-152.

19. Attia EA, El Shennawy D, Sefin A. Serum Interleukin-4 and Total Immunoglobulin E in Nonatopic Alopecia Areata Patients and HLA-DRB1 Typing. Dermatol Res Pract 2010;2010:503587.

20. Zuel Fakkar NM, Attia EA, Moussa MS. Evaluation of total serum immunoglobulin E in alopecia areata. Egypt Dermatol Online J 2010;6:1-9.

21. Zhao Y, Zhang B, Caulloo S, Chen X, Li Y, Zhang X. Diffuse alopecia areata is associated with intense inflammatory infiltration and CD8+ T cells in hair loss regions and an increase in serum IgE level. Indian J Dermatol Venereol Leprol 2012;78:709-714.

22. Bork J, Dallaire M, Lewis S, Boeck C, Hordinsky M. Childhood alopecia areata and atopy: A significant disease association. Am J Hum Genet 1995;57:619-628.

23. Tan E, Tay YK, Goh CL, Chin Giam Y. The pattern and profile of alopecia areata in Singapore a study of 219 Asians. Int J Dermatol 2002;41:748-753.

24. Roselino AM, Almeida AM, Hippolito MA, Cerqueira BC, Maffei CM, Menezes JB, Vieira RE, Assis SL, Ali SA. Clinical-epidemiologic study of alopecia areata. Int J Dermatol 1996;35:181-184.

25. Whitmont KJ, Cooper AJ. PUVA treatment of alopecia areata totalis and universalis: a retrospective study. Australas J Dermatol 2003;44:106-109.
26. Wüthrich B, Grob PJ, Zisiadis S. Immunologische Untersuchungen bei Alopecia areata [Immunological study of alopecia areata]. Hautarzt 1980;31:495-501.

27. Teraki Y, Imanishi K, Shiohara T. Cytokines in alopecia areata: contrasting cytokine profiles in localized form and extensive form (alopecia universalis). Acta Derm Venereol 1996;76:421-423.

28. Gregoriou S, Papafragkaki D, Kontochristopoulos G, Rallis E, Kalogeromitros D, Rigopoulos D. Cytokines and other mediators in alopecia areata. Mediators Inflamm 2010;2010:928030.

29. Ansel J, Perry P, Brown J, Damm D, Phan T, Hart C, Luger T, Hefeneider S. Cytokine modulation of keratinocyte cytokines. J Invest Dermatol 1990;94:101-107.

30. Symington FW. Lymphotoxin, tumor necrosis factor, and gamma interferon are cytostatic for normal human keratinocytes. J Invest Dermatol 1989;92:798-805.

31. Altin J, Shen C, Liston A. Understanding the genetic regulation of IgE production. Blood Rev 2010;24:163-169.

32. Kuwano Y, Fujimoto M, Watanabe R, Ishiura N, Nakashima H, Ohno Y, Yano S, Yazawa N, Okochi H, Tamaki K. Serum BAFF and APRIL levels in patients with alopecia areata. J Dermatol Sci 2008;50:236-239.

33. Mackay F, Schneider P, Rennert P, Browning J. BAFF AND APRIL: a tutorial on B cell survival. Annu Rev Immunol 2003;21:231-264.

34. Mackay F, Leung $\mathrm{H}$. The role of the BAFF/APRIL system on T cell function. Semin Immunol 2006;18:284-289.

35. Splawski JB, Fu SM, Lipsky PE. Immunoregulatory role of CD40 in human B cell differentiation. J Immunol 1993;150:1276-1285.

36. Zhang L, Weetman AP, Friedmann PS, Oliveira DB. HLA associations with alopecia areata. Tissue Antigens 1991;38:89-91.

37. Sato-Kawamura M, Aiba S, Tagami H. Strong expression of CD40, CD54 and HLA-DR antigen and lack of evidence for direct cellular cytotoxicity are unique immunohistopathological features in alopecia areata. Arch Dermatol Res 2003:294:536-543.

38. Güleç AT, Tanriverdi N, Dürü C, Saray Y, Akçali C. The role of psychological factors in alopecia areata and the impact of the disease on the quality of life. Int J Dermatol 2004;43:352-356.

39. Manolache L, Benea V. Stress in patients with alopecia areata and vitiligo. J Eur Acad Dermatol Venereol 2007:21:921-928. 